\title{
Hypothesis
}

\section{Prion Protein PRNP: A New Player in Innate Immunity? The $A \beta$ Connection}

\author{
Richard Lathe $^{\mathrm{a}, \mathrm{b}, *}$ and Jean-Luc Darlix ${ }^{\mathrm{c}, *}$ \\ ${ }^{a}$ Division of Infection and Pathway Medicine, University of Edinburgh, Edinburgh, UK \\ ${ }^{\mathrm{b}}$ Shemyakin and Ovchinnikov Institute of Bioorganic Chemistry, Russian Academy of Sciences, \\ Pushchino, Moscow Region, Russia \\ ${ }^{\mathrm{c}}$ Faculté de Pharmacie, Centre Nationale de la Recherche Scientifique (CNRS) Unité 7213, \\ Université de Strasbourg, Illkirch, France
}

Accepted 11 November 2017

\begin{abstract}
The prion protein PRNP has been centrally implicated in the transmissible spongiform encephalopathies (TSEs), but its normal physiological role remains obscure. We highlight emerging evidence that PRNP displays antimicrobial activity, inhibiting the replication of multiple viruses, and also interacts directly with Alzheimer's disease (AD) amyloid- $\beta$ (A $\beta$ ) peptide whose own antimicrobial role is now increasingly secure. PRNP and A $\beta$ share membrane-penetrating, nucleic acid-binding, and antiviral properties with classical antimicrobial peptides such as LL-37. We discuss findings that binding of abnormal nucleic acids to PRNP leads to oligomerization of the protein, and suggest that this may be an entrapment and sequestration process that contributes to its antimicrobial activity. Some antimicrobial peptides are known to be exploited by infectious agents, and we cover evidence that PRNP is usurped by herpes simplex virus (HSV-1) that has evolved a virus-encoded 'anti-PRNP' function. These findings suggest that PRNP, like LL-37 and A $\beta$, is likely to be a component of the innate immune system, with implications for the pathoetiology of both AD and TSE.
\end{abstract}

Keywords: Alzheimer's disease, amyloid- $\beta$ peptide, herpes simplex, innate immunity, PRNP, spongiform encephalopathy

\section{INTRODUCTION}

Several brain conditions, including Alzheimer's disease $(\mathrm{AD})$ and the transmissible spongiform encephalopathies (TSEs)—Creutzfeld-Jakob disease (CJD) in human, scrapie in sheep, and bovine spongiform encephalopathy (BSE) in cattle-are associated with the presence of abnormal protein deposits in brain. For years it was thought that the amyloid- $\beta(\mathrm{A} \beta)$ in $\mathrm{AD}$ brain might cause the disease,

\footnotetext{
${ }^{*}$ Correspondence to: Richard Lathe, Division of Infection and Pathway Medicine, University of Edinburgh, Edinburgh, UK. E-mail: richardlathe@ed.ac.uk; Jean-Luc Darlix, Faculté de Pharmacie, Centre Nationale de la Recherche Scientifique (CNRS) Unité 7213, Université de Strasbourg, 74 Route du Rhin, 67401 Illkirch Cédex, Illkirch, France. E-mail: jldarlix @ gmail.com.
}

but emerging evidence argues that $\mathrm{A} \beta$ is an antimicrobial defense peptide induced in response to infection [1-5], raising the prospect that AD might be associated with brain infection (e.g., [6]). Indeed, it has been argued, notably by Kagan and colleagues, that amyloid peptides in general may have antimicrobial properties [7, 8]. This paper addresses whether PRNP, the central component of the proteinaceous 'prion' deposits found in the TSE disease brain, might also have antimicrobial activity.

Starting with a brief overview of prion theory, this article examines findings that PRNP associates directly with the antimicrobial peptide $A \beta$, that PRNP and $A \beta$ are codeposited in disease brain, and that PRNP (like A $\beta$ ) binds to both membranes and nucleic acids and displays antiviral activity. We then examine 
in more depth how herpes simplex virus (HSV-1) usurps PRNP protein. We conclude by examining the nucleic acid-binding properties of PRNP, and suggest that oligomerization of the protein in response to abnormal nucleic acids may represent an entrapment and sequestration mechanism as a central component of PRNP antimicrobial activity.

\section{PRION DISEASE}

TSEs include diverse neurodegenerative diseases, including scrapie in sheep, BSE in cattle, and CJD in human. For more than 40 years it has been known that brain tissues from individuals with TSE diseases contain aggregated protein deposits [9-11]. These fractions are infectious upon reinoculation into a new host, and infectious fractions are enriched in proteaseresistant aggregates of the host protein 'PrP' $[12,13]$, a processing product of the native precursor protein, PRNP, encoded by the PRNP gene in human, Prnp in mouse.

The basic tenet of the prion theory $[14,15]$ is that, in disease, a cellular form of PRNP, dubbed $\operatorname{PrP}^{\mathrm{c}}$, undergoes a conformation change, generating the 'scrapie-specific' form $\operatorname{PrP}^{\mathrm{sc}}$. In turn, $\operatorname{PrP}^{\mathrm{Sc}}$ binds to $\operatorname{PrP}^{\mathrm{c}}$ and promotes $\operatorname{PrP}^{\mathrm{c}} \longrightarrow \operatorname{PrP}^{\mathrm{sc}}$ conversion, leading to amplification of (supposedly neurotoxic) $\mathrm{PrP}^{\mathrm{sc}}$ and disease ([16-18] for review).

In support of the protein-only hypothesis, no agent other than PRNP protein has been routinely detected in purified infectious fractions from disease brain. Moreover, the agent is resistant to some treatments that normally inactivate nucleic acids, and any prospective nucleic acid that might be associated with infectious PRNP must be short [19], thereby excluding a conventional virus. However, this has been widely debated (e.g., [20-23] and references therein) and, although innate immune cells and molecules including interferons and interleukins have been implicated in TSE disease progression (reviewed in [24]), the precise pathoetiology of TSEs and the normal role of PRNP remain enigmatic.

\section{PRNP IS WIDELY DISTRIBUTED IN INTRACELLULAR AND EXTRACELLULAR COMPARTMENTS}

PRNP is generally thought of as a cell-surface molecule that is attached to the membrane by a glycosyl phosphatidylinositol (GPI) anchor. However, common PRNP isoforms lacking the GPI anchor are widely distributed across multiple intracellular compartments, including the nucleus, as well as in the extracellular milieu. The human, mouse, hamster, and sheep PRNP coding sequences contain methionine triplets downstream of the usual initiation codon, and $10-15 \%$ of PRNP polypeptides in human and hamster are generated by translation initiation at these downstream sites [25], generating an intracellular protein. Cell-surface PRNP is also cleaved by $\alpha$-secretase and other cellular proteases to liberate extracellular fragments (e.g., [26-28]) or is released from the membrane by the action of phospholipases; furthermore, cell-surface and extracellular PRNP can be re-internalized by several routes including direct endocytosis (e.g., [29-31]).

Expressed widely in multiple tissues including the immune system, the true biological role of PRNP has remained elusive, and laboratory pathogen-free Prnp knockout mice display only subtle and irreproducible deficits in parameters such as synaptic plasticity (not reviewed). As we will see, binding partners of PRNP may cast light on its role.

\section{PRNP BINDS TO A $\beta$}

It has recently emerged that the $A D$ peptide $A \beta$ is a potent antimicrobial molecule that mediates broadspectrum resistance against a variety of infectious agents including viruses, bacteria, and yeasts [1-5]. An interaction between PRNP and $A \beta$ could argue that the two polypeptides are components of the same pathway.

The first indication that PRNP interacts with APPderived molecules came from investigation of PRNP binding partners. Schmitt-Ulms et al. performed in vivo crosslinking of normal mouse brain proteins with formaldehyde; stable complexes were retrieved using anti-PRNP antibody and bound proteins were analyzed by mass spectrometry. APP fragments were among the major binding partners of PRNP [32], indicating that the two proteins are in close proximity in the absence of disease.

Lauren et al. [33] subsequently performed a screen of 225000 mouse cDNA clones for polypeptides binding specifically to $A \beta$ : only two positive clones were retrieved, and both corresponded to PRNP. Binding did not require the disease-specific $\operatorname{PrP}^{\mathrm{sc}}$ configuration. High-affinity binding has been confirmed for human PRNP [34-36]; these studies report two $A \beta$ binding sites within PRNP, one within a central segment (residues 95-110) and a second 


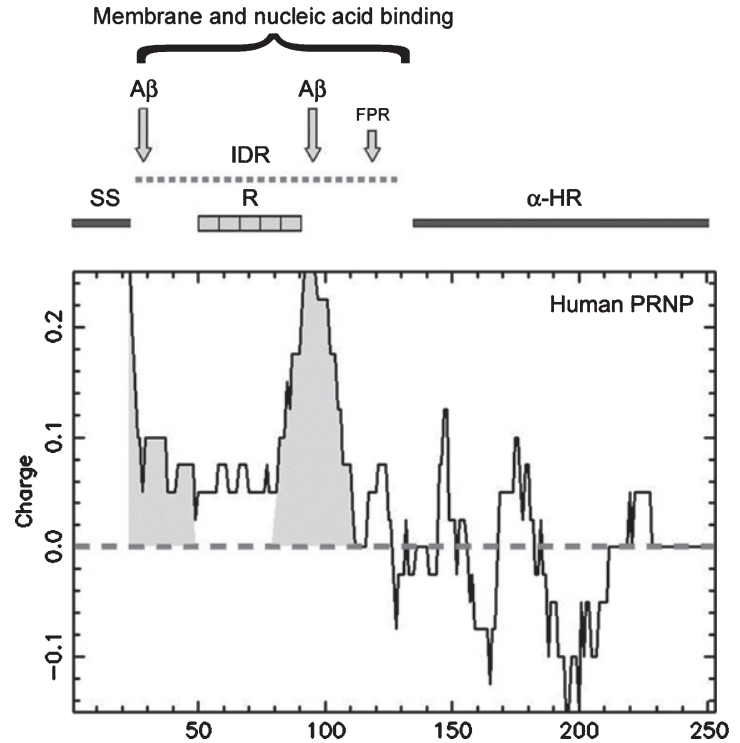

Fig. 1. Domains of Human PRNP Protein. The graph plots the charge of the mature protein (residues 23-253) analyzed with EMBOSS (http://www.bioinformatics.nl/cgi-bin/emboss/charge; windowsize $=20$ ). Grey, basic regions. Abbreviations: $A \beta$, binding sites for $\mathrm{A} \beta$ peptide; FPR, formyl peptide receptor binding site; $\alpha$-HR, $\alpha$-helical region; IDR, intrinsically disordered region; $\mathrm{R}$, octapeptide repeats; $\mathrm{SS}$, signal sequence.

close to the N-terminus (residues 23-27) (Fig. 1). A direct interaction between $A \beta$ and PRNP has now been demonstrated by multiple biochemical and biophysical techniques including immunoprecipitation, tagged recombinant proteins, surface plasmon resonance, dissociation-enhanced lanthanide fluorescence immunoassay, and fluorescence polarization (e.g., [37, 38]).

Interestingly, in the study of Schmitt-Ulm et al. [32], other proteins binding to PRNP in this assay included the APP-like protein APLP2 and APOE; this latter is notable because APOE is an immune mediator [39] and mutations in APOE govern susceptibility to AD (reviewed in [40]). Indeed, APOE also binds to $\mathrm{A} \beta$, and $A P O E$ alleles also modulate susceptibility to several different microbes (e.g., Chlamydophila, Klebsiella, malaria, hepatitis C, HIV, HSV; not reviewed), as well as to CJD (e.g., [41]).

\section{PRNP and A $\beta$ are codeposited in disease brain}

Do PRNP and $A \beta$ associate in disease brain in vivo? Esiri and colleagues [42] screened brain samples from unselected postmortem cases, and reported that in $42 \%$ of cases low levels of PRNP immunoreactivity were associated with AD-type plaques.
A similar finding of punctate PRNP immunoreactivity in $\mathrm{AD}$ plaques was reported by Ferrer et al. [43], whereas Kovacs found colocalization with tau aggregates in AD [44], another signature of the disease. More recently it has been reported that $A \beta$ predominantly interacts with aggregated forms of PRNP in AD brain [36, 45]. Zou et al. reported that $\mathrm{A} \beta$ in $\mathrm{AD}$ brain forms coaggregates with a $\mathrm{PrP}^{\mathrm{sc}}$-like form of the molecule, termed $\mathrm{PrP}^{\mathrm{i}}$, that copurifies with $A \beta$ on gel filtration, and the two proteins coimmunoprecipitate with either anti-A $\beta$ or anti-PRNP antibody from extracts of human AD brain [36].

Similar interactions are reported in TSE. Hainfellner et al. [46] analyzed brain samples from individuals with confirmed CJD and non-CJD controls. AD-type pathology was seen in 10-20\% of both groups, which the authors ascribed to age-related changes, but it was observed that PRNP deposits frequently accumulate at the periphery of $A \beta$ plaques.

Colocalization has also been reported in mice. For example, in double Prnp/App transgenic mice-expressing AD-associated mutant APP as well as hamster PRNP-extensive brain amyloid deposition was seen, and A $\beta$ and PRNP colocalized in almost all plaques [47].

On balance it appears that, when PRNP amyloid is present, in both $\mathrm{AD}$ and TSE, it tends to colocalize with $A \beta$ plaques, providing evidence that the interaction detected in vitro is reiterated in vivo. This supports the view that the two polypeptides are part of the same biological pathway.

PRNP promotes the generation and fibrillization of $A \beta$ in disease

In further support of an interaction, Parkin et al. [48] studied the effect of PRNP on the release of $\mathrm{A} \beta$ peptide from its precursor protein APP. In AD, two specific protease cleavages are required to release $\mathrm{A} \beta$-one at the $\mathrm{N}$-terminus, the so-called $\beta$-secretase site, and a second at the $\mathrm{C}$-terminus of the molecule, the $\gamma$-secretase site. Downregulation of PRNP by antisense or knockout led to increased levels of $A \beta$ processing; the authors inferred that PRNP normally inhibits $\beta$-secretase cleavage and $A \beta$ release [48]. It was suggested that $\operatorname{PrP}^{\mathrm{c}} \longrightarrow \operatorname{PrP}^{\text {sc }}$ conversion may release inhibition, leading to dual upregulation of $\mathrm{PrP}^{\mathrm{sc}}$ and $\mathrm{A} \beta$ in disease, consistent with a synergistic role for the two peptides. Indeed, $A \beta$ levels are increased several-fold in TSE infection [48, 49]. In addition, there is evidence from knockout cells 
that PRNP not only promotes $A \beta$ release but also fibrillization of the molecule [50].

\section{PRNP alleles constitute a risk factor for $A D$}

If $\mathrm{AD}$-related $\mathrm{A} \beta$ interacts with PRNP, then different allelic variants of $P R N P$ might be anticipated to modulate $A \beta$ function. An association between PRNP mutations and AD has been documented. Several studies have addressed the specific linkage between the common codon 129 polymorphism (a risk factor for CJD) and $\mathrm{AD}$, but failed to find an association (e.g., [51]). However, when the influence of $A P O E$ alleles was taken into account, PRNP variants were reported as a significant contributing factor to AD (e.g., [52, 53]). Different meta-analyses of $P R N P$ variants have reported a positive association between $P R N P$ with AD [54-56], and indeed carriers of some $P R N P$ mutations are primarily diagnosed as $\mathrm{AD}$ (e.g., [57]). In short, $P R N P$ genotype is a modifier of $\mathrm{AD}$ risk, arguing again that the in vitro interaction between PRNP and A $\beta / A P P$ is functional in vivo.

\section{EVIDENCE THAT PRNP IS ITSELF A DEFENSE MOLECULE}

The above studies demonstrate that PRNP is a primary binding partner of the antimicrobial peptide $A \beta$, both in vitro and in vivo. This opens the possibility that PRNP may also be a component of the innate immune system.

\section{Antimicrobial peptides}

Antimicrobial peptides are a large and diverse group of evolutionarily ancient proteins that pre-date the adaptive immune system. For example, the $A \beta$ sequence is conserved between humans and primitive fish [5]. They have potent activity against a wide range of bacteria, viruses, and yeasts, and classically exert their actions in multiple ways (reviewed in [58-60]). First, by physical association with membranes that can lead to membrane penetration and/or antimicrobial activity via receptor blockade. Second, by recruiting immunomodulators to the site of infection. Third, by the formation of extensive protein networks (amyloids) that act as traps for pathogens, sequestering them into an insoluble fraction from which they cannot escape. Other mechanisms include the local generation of toxic reactive oxygen species, the induction of cell death 'beneficial suicide' pathways (e.g., [61]), and modulation of viral nucleic acid synthesis.

The crucial importance of these broad-specificity anti-infection mechanisms is illustrated by the antimicrobial peptide cathelicidin LL-37; if untreated, genetic deficiency in human leads to death from infection in the first year of life [62].

\section{PRNP resembles an antimicrobial peptide}

PRNP displays many of these properties. First, like $\mathrm{A} \beta$, PRNP is substantially conserved through evolution, and homologs can be traced back to frogs and fish [63]. Second, PRNP shares the membranebinding/inserting [64-69] and nucleic acid-binding properties of classical antimicrobial peptides (discussed in more detail below). Third, PRNP is a powerful immunomodulator (reviewed in [70]) and, like both the classical antimicrobial peptide LL-37 and $A \beta$, PRNP is a ligand for formyl peptide receptors (reviewed in [71]), key components of the innate immune system.

Centrally, the formation of polymeric aggregates by PRNP reiterates the aggregation and pathogen entrapment mechanisms attributed to $A \beta$ and classical antimicrobial peptides. It is plausible to suggest that the $\operatorname{PrP}^{\mathrm{c}}$ to $\operatorname{PrP}^{\mathrm{sc}}$ conversion might be part of a pathway paralleling the conversion of APP to A $\beta$ and subsequent aggregation and entrapment activity (discussed further below), perhaps in direct physical association with $\mathrm{A} \beta$.

In addition, for several antimicrobial peptides, copper binding permits the generation of reactive oxygen species that contribute to the inactivation of bound pathogens. Like the recently uncovered antimicrobial peptide $A \beta$, PRNP binds tightly to copper ion $[72,73]$. It is not yet known whether copper binding contributes to the immune defense properties of PRNP, and further work in this direction is warranted.

Finally, like other innate immune molecules, PRNP expression is upregulated by infection. Cellular infection with HIV-1 leads to increased PRNP mRNA levels [74]. Upregulation was reported following infection with, among others, vesicular stomatitis virus and murine leukemia virus [75], adenovirus 5 [76, 77], hepatitis $\mathrm{C}$ virus [78, 79], Epstein-Barr virus [80], and Mycobacterium bovis [81]. Similar findings have been reported in vivo, and PRNP was upregulated in brain of individuals infected with HIV-1 as well as in cases of simian immunodeficiency virus encephalitis in macaques [82]. Interestingly, Voigtländer et al. reported striking 
Table 1

Antiviral Effects of PRNPa

\begin{tabular}{lll}
\hline Virus inhibited & Virus type & Ref. \\
\hline Adenovirus 5 & dsDNA virus, non-enveloped & [77] \\
Coxsackievirus B3 & ss(+)RNA virus, non-enveloped & {$[85]$} \\
HIV-1 & Retrovirus, ss(+)RNA, enveloped & {$[84]$} \\
HSV-1 virus (del68) & dsDNA virus, enveloped & {$[89]$} \\
Murine leukemia virus & Retrovirus, ss(+)RNA, enveloped & {$[87]$} \\
Poliovirus type 1 & Picornavirus, ss(+) RNA, non-enveloped & {$[86]$} \\
\hline
\end{tabular}

upregulation of PRNP in AD [83], a condition now increasingly linked to infection [6]. Notably, the formation of the $\operatorname{PrP}^{\mathrm{sc}}$ form is induced by HIV-1 infection [84].

\section{Antimicrobial activity of PRNP}

There is direct evidence that PRNP plays a direct protective role in defense against virus infection (the special case of wild-type HSV is examined in the next section). In cell culture, titers of coxsackievirus B3 were 30-100-fold higher in Prnp knockout cells, and cells could be rescued by expression of PRNP. Protection corresponded to increased interferon production and elevated apoptotic cell death as assessed by DNA fragmentation [85]. Expression of PRNP decreased HIV-1 gene expression and virus production was reduced by eightfold [84]. Similar findings have been reported for poliovirus type 1 , where the titer of virus was increased by a factor of $10^{2}$ to $10^{4}$ in Prnp knockout cells, and virus replication was blocked by re-expression of PRNP [86]. Prnp knockout was associated with a fivefold increase in expression of murine leukemia virus [87]. Also in cell culture, antisense blockade of PRNP expression increased adenovirus 5 mRNA and DNA content by up to 10-fold [77].

In vivo, although titers of encephalomyocarditis virus were not significantly different between Prnp wild-type and knockout mice following intracerebral inoculation, wild-type mice had higher levels of brain inflammation consistent with a more active response [88]. Convincingly, however, in vivo titers of a mutant HSV-1 virus (del68) were reduced by a factor of 600 in wild-type versus Prnp knockout mice ([89], discussed further below).

Although more in vivo studies are required, together these data indicate that PRNP, that is itself upregulated in response to infection, leads to a dramatic fall (in the range $10^{1}$ to $10^{4}$ ) in the proliferation of a diverse range of viruses (Table 1); one may reliably conclude that PRNP is a defense molecule.

\section{HSV-1 HIGHLIGHTS PRNP-DEPENDENT AUTOPHAGY AS A MECHANISM OF ANTIVIRAL DEFENSE}

As noted earlier, antimicrobial peptides typically have multiple modes of action that centrally involve membrane association. However, there is one area in which we are beginning to understand the mechanism of action of PRNP in antiviral defense, and studies on HSV-1 have been crucial. Indeed, the very first studies on PRNP and virus resistance employed HSV-1, but at that time it was not known that HSV1 deploys an 'anti-PRNP' strategy which has been highly informative.

Titers of the HSV-1 mutant del68 (ICP34.5) are reduced 600-fold in wild-type versus Prnp knockout cells [89], as noted earlier. In vivo, all wild-type animals infected with the mutant virus survived, whereas the majority of Prnp knockout animals died following infection, demonstrating the protective role of PRNP. By contrast, the wild-type virus displays an entirely different pattern (next section).

It now emerges that wild-type HSV-1 virus has a specific 'anti-PRNP' function. Orvedahl et al. [90] reported that the virus function in question, ICP34.5 (infected cell polypeptide $34.5 \mathrm{kDa}$, that is altered in the del68 mutant), binds to BECLIN1, a protein involved in autophagy - a process in which a section of the cytoplasm is enclosed in an isolation membrane to generate 'autophagosomes', that then fuse with lysosomes to permit degradation of the contents, including infectious agents (reviewed in [91]).

Using a HSV ICP34.5 mutant selectively deficient in BECLIN1 binding, Korom et al. [89] demonstrated that PRNP normally blocks the neurovirulence of the virus by targeting the virus for autophagosomemediated degradation. In the absence of ICP34.5, a PRNP-dependent process is set in train that blocks virus proliferation by autophagic mechanisms. However, in wild-type virus (isolate 17) ICP34.5 stops this process in its tracks, permitting virus proliferation [89]. 


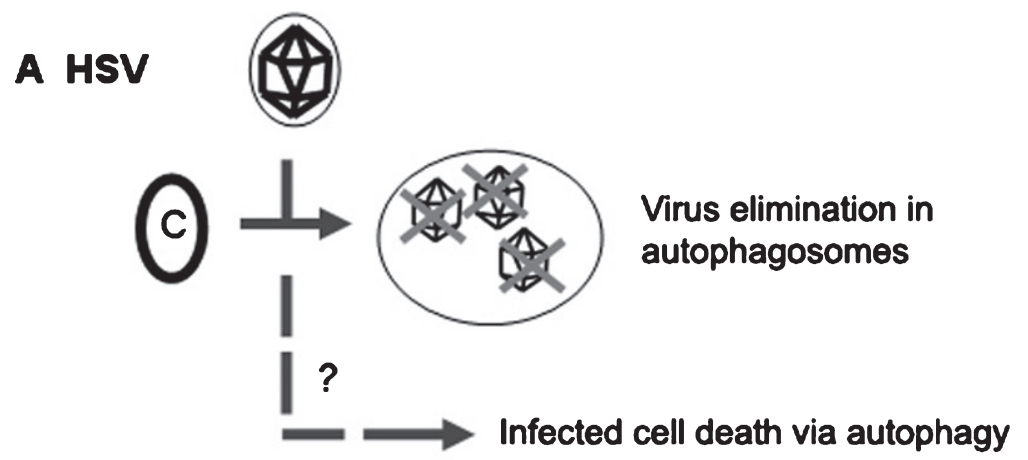

B Abnormal nucleic acids

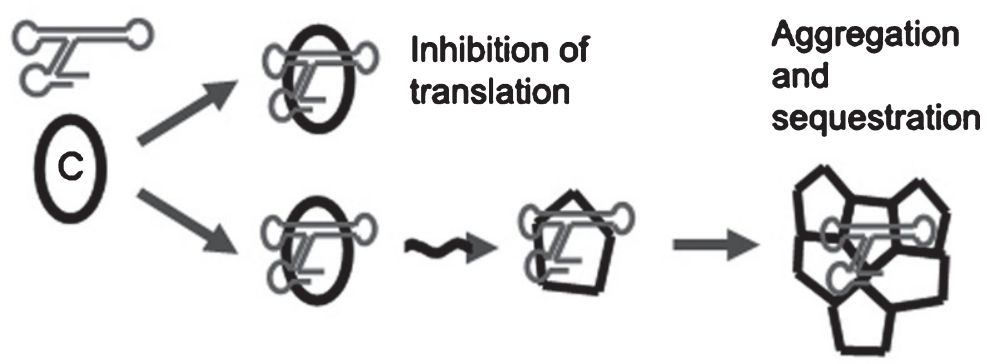

\section{A $\beta$ processing}
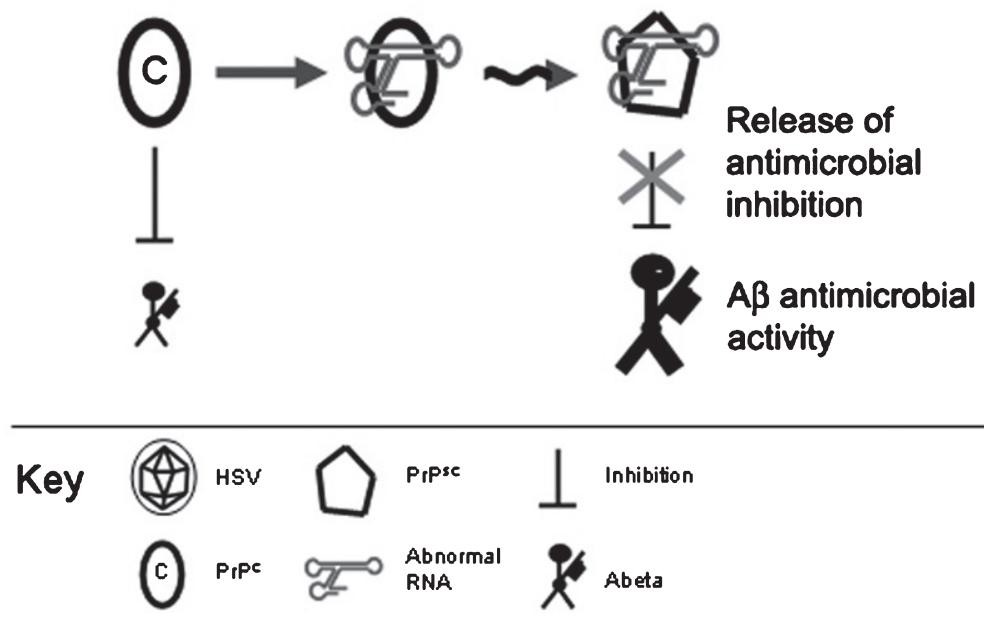

Fig. 2. Antimicrobial Activities of PRNP. In addition to the listed categories, other mechanisms are likely to include the generation of reactive oxygen species, and binding to immunomodulatory molecules including APOE and formyl peptide receptors is likely to direct the recruitment of other actors in innate immunity. Direct binding to $A \beta$ (not depicted) and potential interactions with other antimicrobial peptides that bind to A $\beta$ (e.g., LL-37, $\alpha$-synuclein) add a further dimension. Abbreviation: HSV, herpes simplex virus type 1.

These elegant studies demonstrate that autophagy induction in response to virus infection is one major route by which PRNP exerts antiviral activity. However, it is unlikely to be the only one, and distinct targeted defense mechanisms may be invoked against different infectious agents (Fig. 2). Moreover, as we will see in the next section, HSV usurps PRNP.

\section{HSV-1 NOT MERELY BLOCKS, BUT EXPLOITS, PRNP}

In apparent conflict with antimicrobial role of PRNP, it was earlier reported that wild-type HSV-1 is not inhibited by PRNP, but in fact needs PRNP for efficient proliferation. The discovery of the HSV-1- 
encoded 'anti-PRNP' function discussed above now provides fresh insights into these earlier reports.

In a key paper, Thackray and Bujdoso [92] reported that Prnp knockout mice are in fact much less sensitive to wild-type HSV-1 (isolate SC16) than are Prnp wild-type mice, and the survival of mice following lethal challenge was remarkably increased by Prnp knockout. Conversely, overexpression of wild-type PRNP dramatically boosted virus proliferation. In a follow-up paper, the same group confirmed earlier findings and reported significantly increased acute virus titers in brainstem of wild-type versus knockout animals [93].

These instrumental data indicate that, in addition to blocking PRNP-dependent antiviral autophagy, wildtype HSV-1 depends upon, and usurps, PRNP to foster virus proliferation. This is not unprecedented. HIV-1 exploits the classical antimicrobial peptide LL-37 to promote its own replication [94], and viruses such as HIV-1 and HSV-1 exploit cell-surface immunoreceptors which normally stimulate immunity to facilitate virus infection of immune cells. The mechanism by which HSV-1 usurps PRNP remains unknown, but may involve membrane interactions and/or nucleic acid binding (below).

\section{ANTIMICROBIAL PEPTIDES ALSO BIND TO NUCLEIC ACIDS}

Because antimicrobial peptides centrally target membranes as part of their antimicrobial activity $[60,95]$, they often also bind to nucleic acids. In vertebrates, membranes are highly enriched in negatively charged molecules including phospholipids and sulfated glycosaminoglycans, and bacterial membranes containing teichoic acids and lipopolysaccharides are also negatively charged. Thus, many antimicrobial peptides also bind to nucleic acids.

LL-37 has been shown to bind tightly to extracellular DNA plasmids and oligonucleotides [96, 97]. It can also migrate to the nucleus and modulate gene transcription [98]. Similar findings have been reported for $A \beta$. Structural analysis indicated that $\mathrm{A} \beta$ exhibits the signature characteristics of a nucleic acid-binding protein [99]. Moreover, direct binding to DNA has been described [100-104], and A $\beta$ is reported to enter the nucleus to bind directly to DNA to modulate transcription, targeting a specific $A \beta-$ interacting domain in the promoter regions of the key $A P P, B A C E 1$, and $A P O E$ gene promoters [105]. Nucleic acid binding by $A \beta$ may also contribute to its antiviral effects, such as by interfering with reverse transcription activity. For example, Wang et al. [106] found that $A \beta$ oligomers, but not monomers, robustly inhibited the reverse transcription activity of vertebrate telomerase enzyme TERT, probably by binding to the substrate RNA/DNA hybrid [106], raising the prospect that $A \beta$ nucleic acid binding might also inhibit the proliferation of retroviruses.

\section{Nucleic acid binding by PRNP: Inhibition of translation and induced $\operatorname{Pr} P^{\mathrm{c}}$ to $\operatorname{Pr} P^{\mathrm{Sc}}$ \\ conversion as a sequestration strategy}

PRNP protein contains two basic regions in the $\mathrm{N}$-terminus of the molecule, and moreover this region of the molecule is an 'intrinsically disordered region' (IDR) (Fig. 1). IDRs can refold around a molecule such as RNA so as to grasp the ligand, and the presence of an IDR is a characteristic of several RNAbinding proteins [107].

It has been established for many years that PRNP binds to nucleic acids $([108,109]$, reviewed in [110, 111]). The presence of two basic regions (Fig. 1) suggests that PRNP may contain two binding sites for nucleic acids. In addition to binding to A $\beta$, PRNP also interacts with several other nucleic acid-binding proteins - RNA-binding proteins were among the most significant hits in a microarray screen for PRNP binding partners [112]. Nucleic acid binding could contribute to the antiviral repertoire of PRNP. We (J.L.D.) previously reported that PRNP binding to HIV-1 mRNA blocks translation of the viral message, and native PRNP inhibited HIV-1 replication [84]. This activity has been confirmed for human, mouse, and hamster PRNP [113], and is thus evolutionarily conserved.

Does PRNP bind to nucleic acids in vivo? The evidence suggests that it does. For example, antibodies and binding proteins against single- and doublestranded DNA efficiently retrieve PRNP from TSE brain (CJD, BSE, scrapie), but not from control brain ([114]; antibodies against RNA were not tested). Importantly, specific nucleic acids precipitate the conversion of $\mathrm{PrP}^{\mathrm{c}}$ to $\mathrm{PrP}^{\mathrm{Sc}}$, in which the protein refolds to adopt a $\beta$-sheet configuration and subsequently aggregates. Different nucleic acids differ in their ability to catalyze this transition. Binding of DNA can stimulate the $\beta$-sheet conversion, but aggregation is inhibited [109]. In detailed studies, Zeiler et al. [115] and Adler et al. [116] reported that different RNAs have widely different affinities for $\operatorname{PrP}^{\mathrm{c}}$, with the highest binding being displayed 
by highly structured RNAs with multiple doublestranded regions. In addition, only highly structured RNAs perturbed the conformation of PRNP in such a way as to promote the conversion of PRNP $\left(\operatorname{PrP}^{\mathrm{c}}\right)$ to $\operatorname{PrP}^{\mathrm{Sc}}$ [116]. The exact structural features are not yet known, although it was speculated that PRNP might be a sensor of abnormal RNAs containing nonWatson-Crick base pairs in double-stranded RNA [115], or of other motifs such as adjacent hairpins or quadriplex structures [117], and further work in this direction is certainly warranted.

We surmise that disease-associated aggregation of PRNP is likely to contribute to host defense, as it is for other antimicrobial peptides such as $A \beta$ [5]. In the case of $A \beta$ the specific trigger is not yet known, but for PRNP binding of specific abnormal RNAs causes refolding of the molecule and generation of the aggregation-prone $\mathrm{PrP}^{\mathrm{Sc}}$ form. Although this remains to be formally demonstrated, one may legitimately speculate that abnormal RNAs will thus become entrapped in an insoluble aggregate where they can no longer participate in cellular metabolism. Plausibly, sequestration of abnormal RNAs could be a component of the antimicrobial repertoire of PRNP (Fig. 2).

\section{CONCLUDING REMARKS}

We have reviewed the enigmatic antiviral and proviral roles of PRNP, as well as binding of PRNP to $\mathrm{AD} \mathrm{A} \beta$, a protein that is itself increasingly implicated as an antimicrobial agent [1-5]. The antimicrobial activities of both PRNP and A $\beta$ lend support to the theory that amyloid peptides may generally have antimicrobial activity $[7,8]$.

Both PRNP and A $\beta$ are high-profile molecules associated with human disease, and have thus been subject to intense scrutiny. Possible association of PRNP with other components of the innate immune system in addition to $A \beta$ has been less well investigated. Indeed, subtle deficits in cellular immunity have been reported in Prnp knockout mice [118], and PRNP has been implicated in defense against other forms of immunological and pathophysiological stress [119]. It is notable that both PRNP and A $\beta$ interact with the immunomodulatory protein APOE $[32,120]$, and a functional interaction between PRNP and $\alpha$-synuclein, the protein deposited in Parkinson's disease brain, has also been reported [121], of importance because of recent evidence that $\alpha$-synuclein itself could be an antimicrobial peptide [122-124], lending further weight to the suggestion that amyloid peptides may generally have antimicrobial activity $[7,8]$.

Potential interactions with other components of the innate immune system such as LL-37, APPand PRNP-like molecules, and other actors remain to be addressed in detail. Indeed, an interaction between $A \beta$ and LL-37 has recently been uncovered [125], and $\alpha$-synuclein was first discovered as a molecule that, like PRNP, binds with high affinity to $A \beta$ ([126]; reviewed in [127]). This raises the question of whether these molecules associate in a complex that appears to contain PRNP, APP/A $\beta$ and paralogs, APOE, other antimicrobial peptides, and RNA-binding proteins, among others. Do these constitute a multiprotein complex that is sprung into action following infection, and, if so, how would this process be triggered?

The prominent antiviral activity of PRNP (Table 1), reinforced by the finding that evolution has led HSV-1 to develop an 'anti-PRNP' function, argues that PRNP plays a role in innate immunity; PRNP oligomerization in response to binding of abnormal nucleic acids is also consistent with an innate immune defense strategy. It is also an intriguing fact that chain-terminating mutations in human PRNP are not only associated with brain disease, but chronic diarrhea is also a prominent feature in these patients [57], a typical presentation of innate immune deficiency (e.g., NOD2 mutations in irritable bowel syndrome). By contrast, cattle and goats lacking PRNP appear to be overtly healthy [128, 129], although the extent to which PRNP-like genes (doppel, $P R N D$, and shadoo, $S P R N$ ) might substitute for PRNP function in ruminants is not known, and the PRNP-deficient Norwegian goat line displays elevated levels of interferon-responsive gene expression that could be compatible with subclinical infection [130]. Direct challenge experiments have not been done.

Although in many scenarios PRNP acts to block viral proliferation, PRNP appears to be usurped and exploited by HSV-1. This is not unprecedented; for example, the classical antimicrobial peptide LL-37 stimulates, rather than inhibits, the life cycle of HIV-1 [94]. Looking wider, an antimicrobial role for PRNP may have implications for the pathoetiology of both TSEs and AD. Time will also tell whether other agents, in addition to HSV-1, might usurp the host defense roles of PRNP and/or A $\beta$ to ensure their own proliferation; further research into the roles of PRNP and A $\beta$ in innate immunity to infec- 
tious agents is clearly warranted. To close, we quote Brentani and colleagues a decade ago: Time is ripe for examining possible loss-of-immune-function components of prion diseases in the context of peripheral infection [70].

\section{ACKNOWLEDGMENTS}

This research did not receive any specific grant funding from funding agencies in the public, commercial, or not-for-profit sectors. We would like to thank Ruth Itzhaki for critical reading of the manuscript.

\section{CONFLICT OF INTEREST}

The authors have no conflict of interest to report.

\section{REFERENCES}

[1] Soscia SJ, Kirby JE, Washicosky KJ, Tucker SM, Ingelsson M, Hyman B, Burton MA, Goldstein LE, Duong S, Tanzi RE, Moir RD (2010) The Alzheimer's disease-associated amyloid beta-protein is an antimicrobial peptide. PLoS One 5, e9505.

[2] White MR, Kandel R, Tripathi S, Condon D, Qi L, Taubenberger J, Hartshorn KL (2014) Alzheimer's associated beta-amyloid protein inhibits influenza A virus and modulates viral interactions with phagocytes. PLoS One 9, e101364.

[3] Bourgade K, Garneau H, Giroux G, Le Page AY, Bocti C, Dupuis G, Frost EH, Fulop Jr T (2015) Beta-amyloid peptides display protective activity against the human Alzheimer's disease-associated herpes simplex virus-1. Biogerontology 16, 85-98.

[4] Bourgade K, Le PA, Bocti C, Witkowski JM, Dupuis G, Frost EH, Fulop Jr T (2016) Protective effect of amyloidbeta peptides against herpes simplex virus-1 infection in a neuronal cell culture model. J Alzheimers Dis 50, 12271241.

[5] Kumar DK, Choi SH, Washicosky KJ, Eimer WA, Tucker S, Ghofrani J, Lefkowitz A, McColl G, Goldstein LE, Tanzi RE, Moir RD (2016) Amyloid-beta peptide protects against microbial infection in mouse and worm models of Alzheimer's disease. Sci Transl Med 8, 340ra72.

[6] Itzhaki RF, Lathe R, Balin BJ, Ball MJ, Bearer EL, Braak H, Bullido MJ, Carter C, Clerici M, Cosby SL, Del Tredici K, Field H, Fulop T, Grassi C, Griffin WS, Haas J, Hudson AP, Kamer AR, Kell DB, Licastro F, Letenneur L, Lövheim H, Mancuso R, Miklossy J, Otth C, Palamara AT, Perry G, Preston C, Pretorius E, Strandberg T, Tabet N, Taylor-Robinson SD, Whittum-Hudson JA (2016) Microbes and Alzheimer's disease. JAlzheimers Dis 51, 979-984.

[7] Kagan BL (2011) Antimicrobial amyloids? Biophys J 100, 1597-1598.

[8] Kagan BL, Jang H, Capone R, Teran AF, Ramachandran S, Lal R, Nussinov R (2012) Antimicrobial properties of amyloid peptides. Mol Pharm 9, 708-717.
[9] Plummer PJ (1946) Scrapie - a disease of sheep: A review of the literature. Can J Comp Med Vet Sci 10, 49-54.

[10] Field EJ, Peat A (1969) Structural changes in scrapie affected brain. Biochem J 114, 19P-20P

[11] Fraser H, Bruce M (1973) Argyrophilic plaques in mice inoculated with scrapie from particular sources. Lancet $\mathbf{1}$, 617-618.

[12] Prusiner SB, McKinley MP, Bowman KA, Bolton DC, Bendheim PE, Groth DF, Glenner GG (1983) Scrapie prions aggregate to form amyloid-like birefringent rods. Cell 35, 349-358.

[13] Barry RA, Kent SB, McKinley MP, Meyer RK, DeArmond SJ, Hood LE, Prusiner SB (1986) Scrapie and cellular prion proteins share polypeptide epitopes. J Infect Dis $\mathbf{1 5 3}$, 848-854.

[14] Prusiner SB (1982) Novel proteinaceous infectious particles cause scrapie. Science 216, 136-144.

[15] Prusiner SB, Gabizon R, McKinley MP (1987) On the biology of prions. Acta Neuropathol 72, 299-314.

[16] Prusiner SB (1998) Prions. Proc Natl Acad Sci U S A 95, 13363-13383.

[17] Weissmann C (2004) The state of the prion. Nat Rev Microbiol 2, 861-871.

[18] Aguzzi A, Calella AM (2009) Prions: Protein aggregation and infectious diseases. Physiol Rev 89, 1105-1152.

[19] Rohwer RG (1984) Scrapie infectious agent is virus-like in size and susceptibility to inactivation. Nature 308, 658662.

[20] Manuelidis L, Sklaviadis T, Manuelidis EE (1987) Evidence suggesting that PrP is not the infectious agent in Creutzfeldt-Jakob disease. EMBO J 6, 341-347.

[21] Bruce ME, Dickinson AG (1987) Biological evidence that scrapie agent has an independent genome. J Gen Virol $\mathbf{6 8}$, 79-89.

[22] Weissmann C (1991) A ‘unified theory' of prion propagation. Nature 352, 679-683.

[23] Botsios S, Manuelidis L (2016) CJD and scrapie require agent-associated nucleic acids for infection. $J$ Cell Biochem 117, 1947-1958.

[24] Bradford BM, Mabbott NA (2012) Prion disease and the innate immune system. Viruses 4, 3389-3419.

[25] Juanes ME, Elvira G, Garcia-Grande A, Calero M, Gasset M (2009) Biosynthesis of prion protein nucleocytoplasmic isoforms by alternative initiation of translation. $J$ Biol Chem 284, 2787-2794.

[26] Vincent B, Paitel E, Saftig P, Frobert Y, Hartmann D, De SB, Grassi J, Lopez-Perez E, Checler F (2001) The disintegrins ADAM10 and TACE contribute to the constitutive and phorbol ester-regulated normal cleavage of the cellular prion protein. J Biol Chem 276, 37743-37746.

[27] Guillot-Sestier MV, Sunyach C, Druon C, Scarzello S, Checler F (2009) The alpha-secretase-derived N-terminal product of cellular prion, N1, displays neuroprotective function in vitro and in vivo. J Biol Chem 284, 3597335986.

[28] Guillot-Sestier MV, Sunyach C, Ferreira ST, Marzolo MP, Bauer C, Thevenet A, Checler F (2012) alphaSecretase-derived fragment of cellular prion, N1, protects against monomeric and oligomeric amyloid beta (Abeta)associated cell death. J Biol Chem 287, 5021-5032.

[29] Shyng SL, Heuser JE, Harris DA (1994) A glycolipidanchored prion protein is endocytosed via clathrin-coated pits. J Cell Biol 125, 1239-1250.

[30] Magalhaes AC, Silva JA, Lee KS, Martins VR, Prado VF, Ferguson SS, Gomez MV, Brentani RR, Prado MA (2002) 
Endocytic intermediates involved with the intracellular trafficking of a fluorescent cellular prion protein. $J$ Biol Chem 277, 33311-33318.

[31] Sunyach C, Jen A, Deng J, Fitzgerald KT, Frobert Y, Grassi J, McCaffrey MW, Morris R (2003) The mechanism of internalization of glycosylphosphatidylinositol-anchored prion protein. EMBO J 22, 3591-3601.

[32] Schmitt-Ulms G, Hansen K, Liu J, Cowdrey C, Yang J, DeArmond SJ, Cohen FE, Prusiner SB, Baldwin MA (2004) Time-controlled transcardiac perfusion crosslinking for the study of protein interactions in complex tissues. Nat Biotechnol 22, 724-731.

[33] Lauren J, Gimbel DA, Nygaard HB, Gilbert JW, Strittmatter SM (2009) Cellular prion protein mediates impairment of synaptic plasticity by amyloid-beta oligomers. Nature 457, 1128-1132.

[34] Chen S, Yadav SP, Surewicz WK (2010) Interaction between human prion protein and amyloid-beta (Abeta) oligomers: Role OF N-terminal residues. J Biol Chem 285, 26377-26383.

[35] Balducci C, Beeg M, Stravalaci M, Bastone A, Sclip A, Biasini E, Tapella L, Colombo L, Manzoni C, Borsello T, Chiesa R, Gobbi M, Salmona M, Forloni G (2010) Synthetic amyloid-beta oligomers impair long-term memory independently of cellular prion protein. Proc Natl Acad Sci U S A 107, 2295-2300.

[36] Zou WQ, et al. (2011) Amyloid-beta42 interacts mainly with insoluble prion protein in the Alzheimer brain. J Biol Chem 286, 15095-15105.

[37] Fluharty BR, Biasini E, Stravalaci M, Sclip A, Diomede L, Balducci C, La VP, Messa M, Colombo L, Forloni G, Borsello T, Gobbi M, Harris DA (2013) An N-terminal fragment of the prion protein binds to amyloid-beta oligomers and inhibits their neurotoxicity in vivo. J Biol Chem 288, 7857-7866.

[38] Bove-Fenderson E, Urano R, Straub JE, Harris DA (2017) Cellular prion protein targets amyloid-beta fibril ends via its C-terminal domain to prevent elongation. J Biol Chem 292, 16858-16871.

[39] Mahley RW, Weisgraber KH, Huang Y (2009) Apolipoprotein E: Structure determines function, from atherosclerosis to Alzheimer's disease to AIDS. J Lipid Res 50(Suppl), S183-S188.

[40] Finch CE, Sapolsky RM (1999) The evolution of Alzheimer disease, the reproductive schedule, and apoE isoforms. Neurobiol Aging 20, 407-428.

[41] Amouyel P, Vidal O, Launay JM, Laplanche JL (1994) The apolipoprotein $\mathrm{E}$ alleles as major susceptibility factors for Creutzfeldt-Jakob disease. The French Research Group on Epidemiology of Human Spongiform Encephalopathies. Lancet 344, 1315-1318.

[42] Esiri MM, Carter J, Ironside JW (2000) Prion protein immunoreactivity in brain samples from an unselected autopsy population: Findings in 200 consecutive cases. Neuropathol Appl Neurobiol 26, 273-284.

[43] Ferrer I, Blanco R, Carmona M, Puig B, Ribera R, Rey MJ, Ribalta T (2001) Prion protein expression in senile plaques in Alzheimer's disease. Acta Neuropathol 101, 49-56.

[44] Kovacs GG, Zerbi P, Voigtlander T, Strohschneider M, Trabattoni G, Hainfellner JA, Budka H (2002) The prion protein in human neurodegenerative disorders. Neurosci Lett 329, 269-272.

[45] Dohler F, Sepulveda-Falla D, Krasemann S, Altmeppen H, Schluter H, Hildebrand D, Zerr I, Matschke J, Glatzel M (2014) High molecular mass assemblies of amyloid-beta oligomers bind prion protein in patients with Alzheimer's disease. Brain 137, 873-886.

[46] Hainfellner JA, Wanschitz J, Jellinger K, Liberski PP, Gullotta F, Budka H (1998) Coexistence of Alzheimer-type neuropathology in Creutzfeldt-Jakob disease. Acta Neuropathol 96, 116-122.

[47] Schwarze-Eicker K, Keyvani K, Gortz N, Westaway D, Sachser N, Paulus W (2005) Prion protein (PrPc) promotes beta-amyloid plaque formation. Neurobiol Aging 26, 1177-1182.

[48] Parkin ET, Watt NT, Hussain I, Eckman EA, Eckman CB, Manson JC, Baybutt HN, Turner AJ, Hooper NM (2007) Cellular prion protein regulates beta-secretase cleavage of the Alzheimer's amyloid precursor protein. Proc Natl Acad Sci U S A 104, 11062-11067.

[49] Baier M, Apelt J, Riemer C, Gultner S, Schwarz A, Bamme T, Burwinkel M, Schliebs R (2008) Prion infection of mice transgenic for human APPSwe: Increased accumulation of cortical formic acid extractable Abeta(1-42) and rapid scrapie disease development. Int J Dev Neurosci 26, 821824.

[50] Falker C, Hartmann A, Guett I, Dohler F, Altmeppen H, Betzel C, Schubert R, Thurm D, Wegwitz F, Joshi P, Verderio C, Krasemann S, Glatzel M (2016) Exosomal cellular prion protein drives fibrillization of amyloid beta and counteracts amyloid beta-mediated neurotoxicity. J Neurochem 137, 88-100.

[51] Combarros O, Sanchez-Guerra M, Llorca J, AlvarezArcaya A, Berciano J, Pena N, Fernandez-Viadero C (2000) Polymorphism at codon 129 of the prion protein gene is not associated with sporadic AD. Neurology 55, 593-595.

[52] Golanska E, Hulas-Bigoszewska K, Sieruta M, Zawlik I, Witusik M, Gresner SM, Sobow T, Styczynska M, Peplonska B, Barcikowska M, Liberski PP, Corder EH (2009) Earlier onset of Alzheimer's disease: Risk polymorphisms within PRNP, PRND, CYP46, and APOE genes. J Alzheimers Dis 17, 359-368.

[53] Calero O, Bullido MJ, Clarimon J, Frank-Garcia A, Martinez-Martin P, Lleo A, Rey MJ, Rabano A, Blesa R, Gomez-Isla T, Valdivieso F, de Pedro-Cuesta J, Ferrer I, Calero M (2011) Genetic cross-interaction between APOE and PRNP in sporadic Alzheimer's and Creutzfeldt-Jakob diseases. PLoS One 6, e22090.

[54] Del BR, Scarlato M, Ghezzi S, Martinelli-Boneschi F, Fenoglio C, Galimberti G, Galbiati S, Virgilio R, Galimberti D, Ferrarese C, Scarpini E, Bresolin N, Comi GP (2006) Is M129V of PRNP gene associated with Alzheimer's disease? A case-control study and a metaanalysis. Neurobiol Aging 27, 770.

[55] Bertram L, McQueen MB, Mullin K, Blacker D, Tanzi RE (2007) Systematic meta-analyses of Alzheimer disease genetic association studies: The AlzGene database. Nat Genet 39, 17-23.

[56] He J, Li X, Yang J, Huang J, Fu X, Zhang Y, Fan H (2013) The association between the methionine/valine (M/V) polymorphism (rs1799990) in the PRNP gene and the risk of Alzheimer disease: An update by meta-analysis. J Neurol Sci 326, 89-95.

[57] Guerreiro R, Bras J, Wojtas A, Rademakers R, Hardy J, Graff-Radford N (2014) Nonsense mutation in PRNP associated with clinical Alzheimer's disease. Neurobiol Aging 35, 2656.

[58] Zasloff M (2002) Antimicrobial peptides of multicellular organisms. Nature 415, 389-395. 
[59] Brogden KA (2005) Antimicrobial peptides: Pore formers or metabolic inhibitors in bacteria? Nat Rev Microbiol 3, 238-250.

[60] Jenssen H, Hamill P, Hancock RE (2006) Peptide antimicrobial agents. Clin Microbiol Rev 19, 491-511.

[61] Brinkmann V, Zychlinsky A (2007) Beneficial suicide: Why neutrophils die to make NETs. Nat Rev Microbiol 5, 577-582.

[62] Putsep K, Carlsson G, Boman HG, Andersson M (2002) Deficiency of antibacterial peptides in patients with morbus Kostmann: An observation study. Lancet 360, 1144-1149.

[63] Rivera-Milla E, Oidtmann B, Panagiotidis CH, Baier M, Sklaviadis T, Hoffmann R, Zhou Y, Solis GP, Stuermer CA, Malaga-Trillo E (2006) Disparate evolution of prion protein domains and the distinct origin of Doppel- and prion-related loci revealed by fish-to-mammal comparisons. FASEB $J$ 20, 317-319.

[64] Hegde RS, Mastrianni JA, Scott MR, DeFea KA, Tremblay P, Torchia M, DeArmond SJ, Prusiner SB, Lingappa VR (1998) A transmembrane form of the prion protein in neurodegenerative disease. Science $\mathbf{2 7 9}$, 827-834.

[65] Baron GS, Wehrly K, Dorward DW, Chesebro B, Caughey B (2002) Conversion of raft associated prion protein to the protease-resistant state requires insertion of PrP-res $(\mathrm{PrP}(\mathrm{Sc}))$ into contiguous membranes. EMBO J 21, 10311040

[66] Sanghera N, Pinheiro TJ (2002) Binding of prion protein to lipid membranes and implications for prion conversion. J Mol Biol 315, 1241-1256.

[67] Critchley P, Kazlauskaite J, Eason R, Pinheiro TJ (2004) Binding of prion proteins to lipid membranes. Biochem Biophys Res Commun 313, 559-567.

[68] Zhong J, Zheng W, Huang L, Hong Y, Wang L, Qiu Y, Sha Y (2007) PrP106-126 amide causes the semi-penetrated poration in the supported lipid bilayers. Biochim Biophys Acta 1768, 1420-1429.

[69] Shin JI, Shin JY, Kim JS, Yang YS, Shin YK, Kweon DH (2008) Deep membrane insertion of prion protein upon reduction of disulfide bond. Biochem Biophys Res Commun 377, 995-1000.

[70] Linden R, Martins VR, Prado MA, Cammarota M, Izquierdo I, Brentani RR (2008) Physiology of the prion protein. Physiol Rev 88, 673-728.

[71] He HQ, Ye RD (2017) The formyl peptide receptors: Diversity of ligands and mechanism for recognition. Molecules 22, pii: E455.

[72] Hornshaw MP, McDermott JR, Candy JM, Lakey JH (1995) Copper binding to the N-terminal tandem repeat region of mammalian and avian prion protein: Structural studies using synthetic peptides. Biochem Biophys Res Commun 214, 993-999.

[73] Hornshaw MP, McDermott JR, Candy JM (1995) Copper binding to the $\mathrm{N}$-terminal tandem repeat regions of mammalian and avian prion protein. Biochem Biophys Res Commun 207, 621-629.

[74] Muller WE, Pfeifer K, Forrest J, Rytik PG, Eremin VF, Popov SA, Schroder HC (1992) Accumulation of transcripts coding for prion protein in human astrocytes during infection with human immunodeficiency virus. Biochim Biophys Acta 1139, 32-40.

[75] Lotscher M, Recher M, Hunziker L, Klein MA (2003) Immunologically induced, complement-dependent upregulation of the prion protein in the mouse spleen:
Follicular dendritic cells versus capsule and trabeculae. J Immunol 170, 6040-6047.

[76] Piersanti S, Martina Y, Cherubini G, Avitabile D, Saggio I (2004) Use of DNA microarrays to monitor host response to virus and virus-derived gene therapy vectors. Am J Pharmacogenomics 4, 345-356.

[77] Caruso P, Burla R, Piersanti S, Cherubini G, Remoli C, Martina Y, Saggio I (2009) Prion expression is activated by Adenovirus 5 infection and affects the adenoviral cycle in human cells. Virology 385, 343-350.

[78] Walters KA, Joyce MA, Thompson JC, Smith MW, Yeh MM, Proll S, Zhu LF, Gao TJ, Kneteman NM, Tyrrell DL, Katze MG (2006) Host-specific response to HCV infection in the chimeric SCID-beige/Alb-uPA mouse model: Role of the innate antiviral immune response. PLoS Pathog $\mathbf{2}$, e59.

[79] Hojka-Osinska A, Budzko L, Zmienko A, Rybarczyk A, Maillard P, Budkowska A, Figlerowicz M, Jackowiak P (2016) RNA-Seq-based analysis of differential gene expression associated with hepatitis $\mathrm{C}$ virus infection in a cell culture. Acta Biochim Pol 63, 789-798.

[80] Yuan J, Cahir-McFarland E, Zhao B, Kieff E (2006) Virus and cell RNAs expressed during Epstein-Barr virus replication. J Virol 80, 2548-2565.

[81] Ding T, Zhou X, Kouadir M, Shi F, Yang Y, Liu J, Wang M, Yin X, Yang L, Zhao D (2013) Cellular prion protein participates in the regulation of inflammatory response and apoptosis in BV2 microglia during infection with Mycobacterium bovis. J Mol Neurosci 51, 118-126.

[82] Roberts TK, Eugenin EA, Morgello S, Clements JE, Zink MC, Berman JW (2010) PrPC, the cellular isoform of the human prion protein, is a novel biomarker of HIV-associated neurocognitive impairment and mediates neuroinflammation. Am J Pathol 177, 1848-1860.

[83] Voigtlander T, Kloppel S, Birner P, Jarius C, Flicker $\mathrm{H}$, Verghese-Nikolakaki S, Sklaviadis T, Guentchev M, Budka H (2001) Marked increase of neuronal prion protein immunoreactivity in Alzheimer's disease and human prion diseases. Acta Neuropathol 101, 417-423.

[84] Leblanc P, Baas D, Darlix JL (2004) Analysis of the interactions between HIV-1 and the cellular prion protein in a human cell line. J Mol Biol 337, 1035-1051.

[85] Nakamura Y, Sakudo A, Saeki K, Kaneko T, Matsumoto Y, Toniolo A, Itohara S, Onodera T (2003) Transfection of prion protein gene suppresses coxsackievirus B3 replication in prion protein gene-deficient cells. J Gen Virol 84, 3495-3502.

[86] Baj A, Bettaccini A, Nishimura T, Onodera T, Toniolo A (2005) Poliovirus type 1 infection of murine PRNPknockout neuronal cells. J Neurovirol 11, 237-246.

[87] Lötscher M, Recher M, Lang KS, Navarini A, Hunziker L, Santimaria R, Glatzel M, Schwarz P, Böni J, Zinkernagel RM (2007) Induced prion protein controls immune-activated retroviruses in the mouse spleen. PLoS One 2, e1158.

[88] Nasu-Nishimura Y, Taniuchi Y, Nishimura T, Sakudo A, Nakajima K, Ano Y, Sugiura K, Sakaguchi S, Itohara S, Onodera T (2008) Cellular prion protein prevents brain damage after encephalomyocarditis virus infection in mice. Arch Virol 153, 1007-1012.

[89] Korom M, Wylie KM, Wang H, Davis KL, Sangabathula MS, Delassus GS, Morrison LA (2013) A proautophagic antiviral role for the cellular prion protein identified by infection with a herpes simplex virus 1 ICP34.5 mutant. J Virol 87, 5882-5894. 
[90] Orvedahl A, Alexander D, Talloczy Z, Sun Q, Wei Y, Zhang W, Burns D, Leib DA, Levine B (2007) HSV-1 ICP34.5 confers neurovirulence by targeting the Beclin 1 autophagy protein. Cell Host Microbe 1, 23-35.

[91] Orvedahl A, Levine B (2008) Autophagy and viral neurovirulence. Cell Microbiol 10, 1747-1756.

[92] Thackray AM, Bujdoso R (2002) PrPc expression influences the establishment of herpes simplex virus type 1 latency. J Virol 76, 2498-2509.

[93] Thackray AM, Bujdoso R (2006) Elevated PrPC expression predisposes to increased HSV-1 pathogenicity. Antivir Chem Chemother 17, 41-52.

[94] Ogawa Y, Kawamura T, Matsuzawa T, Aoki R, Gee P, Yamashita A, Moriishi K, Yamasaki K, Koyanagi Y, Blauvelt A, Shimada S (2013) Antimicrobial peptide LL-37 produced by HSV-2-infected keratinocytes enhances HIV infection of Langerhans cells. Cell Host Microbe 13, 77-86.

[95] Hancock RE, Rozek A (2002) Role of membranes in the activities of antimicrobial cationic peptides. FEMS Microbiol Lett 206, 143-149.

[96] Sandgren S, Wittrup A, Cheng F, Jonsson M, Eklund E, Busch S, Belting M (2004) The human antimicrobial peptide LL-37 transfers extracellular DNA plasmid to the nuclear compartment of mammalian cells via lipid rafts and proteoglycan-dependent endocytosis. J Biol Chem 279, 17951-17956.

[97] Zhang X, Oglecka K, Sandgren S, Belting M, Esbjorner EK, Norden B, Graslund A (2010) Dual functions of the human antimicrobial peptide LL-37-target membrane perturbation and host cell cargo delivery. Biochim Biophys Acta 1798, 2201-2208.

[98] Munoz M, Craske M, Severino P, de Lima TM, Labhart P, Chammas R, Velasco IT, Machado MC, Egan B, Nakaya HI, Pinheiro da SF (2016) Antimicrobial peptide LL-37 participates in the transcriptional regulation of melanoma cells. J Cancer 7, 2341-2345.

[99] Mathura VS, Paris D, Ait-Ghezala G, Quadros A, Patel NS, Kolippakkam DN, Volmar CH, Mullan MJ (2005) Model of Alzheimer's disease amyloid-beta peptide based on a RNA binding protein. Biochem Biophys Res Commun 332, 585-592.

[100] Hegde ML, Anitha S, Latha KS, Mustak MS, Stein R, Ravid R, Rao KS (2004) First evidence for helical transitions in supercoiled DNA by amyloid Beta Peptide (1-42) and aluminum: A new insight in understanding Alzheimer's disease. J Mol Neurosci 22, 19-31.

[101] Yu H, Ren J, Qu X (2007) Time-dependent DNA condensation induced by amyloid beta-peptide. Biophys $J \mathbf{9 2}$, 185-191.

[102] Barrantes A, Rejas MT, Benitez MJ, Jimenez JS (2007) Interaction between Alzheimer's Abeta1-42 peptide and DNA detected by surface plasmon resonance. JAlzheimers Dis 12, 345-355.

[103] Geng J, Zhao C, Ren J, Qu X (2010) Alzheimer's disease amyloid beta converting left-handed Z-DNA back to righthanded B-form. Chem Commun (Camb) 46, 7187-7189.

[104] Camero S, Ayuso JM, Barrantes A, Benitez MJ, Jimenez JS (2013) Specific binding of DNA to aggregated forms of Alzheimer's disease amyloid peptides. Int J Biol Macromol 55, 201-206.

[105] Maloney B, Lahiri DK (2011) The Alzheimer's amyloid beta-peptide (Abeta) binds a specific DNA Abetainteracting domain (AbetaID) in the APP, BACE1, and
APOE promoters in a sequence-specific manner: Characterizing a new regulatory motif. Gene 488, 1-12.

[106] Wang J, Zhao C, Zhao A, Li M, Ren J, Qu X (2015) New insights in amyloid beta interactions with human telomerase. J Am Chem Soc 137, 1213-1219.

[107] Calabretta S, Richard S (2015) Emerging roles of disordered sequences in RNA-binding proteins. Trends Biochem Sci 40, 662-672.

[108] Gabus C, Derrington E, Leblanc P, Chnaiderman J, Dormont D, Swietnicki W, Morillas M, Surewicz WK, Marc D, Nandi P, Darlix JL (2001) The prion protein has RNA binding and chaperoning properties characteristic of nucleocapsid protein NCP7 of HIV-1. J Biol Chem 276, 19301-19309.

[109] Cordeiro Y, Machado F, Juliano L, Juliano MA, Brentani RR, Foguel D, Silva JL (2001) DNA converts cellular prion protein into the beta-sheet conformation and inhibits prion peptide aggregation. J Biol Chem 276, 49400-49409.

[110] Silva JL, Lima LM, Foguel D, Cordeiro Y (2008) Intriguing nucleic-acid-binding features of mammalian prion protein. Trends Biochem Sci 33, 132-140.

[111] Gomes MP, Cordeiro Y, Silva JL (2008) The peculiar interaction between mammalian prion protein and RNA. Prion 2, 64-66.

[112] Satoh J, Obayashi S, Misawa T, Sumiyoshi K, Oosumi K, Tabunoki H (2009) Protein microarray analysis identifies human cellular prion protein interactors. Neuropathol Appl Neurobiol 35, 16-35.

[113] Alais S, Soto-Rifo R, Balter V, Gruffat H, Manet E, Schaeffer L, Darlix JL, Cimarelli A, Raposo G, Ohlmann T, Leblanc P (2012) Functional mechanisms of the cellular prion protein $(\operatorname{PrP}(\mathrm{C}))$ associated anti-HIV-1 properties. Cell Mol Life Sci 69, 1331-1352.

[114] Zou WQ, Zheng J, Gray DM, Gambetti P, Chen SG (2004) Antibody to DNA detects scrapie but not normal prion protein. Proc Natl Acad Sci U S A 101, 1380-1385.

[115] Zeiler B, Adler V, Kryukov V, Grossman A (2003) Concentration and removal of prion proteins from biological solutions. Biotechnol Appl Biochem 37, 173-182.

[116] Adler V, Zeiler B, Kryukov V, Kascsak R, Rubenstein R, Grossman A (2003) Small, highly structured RNAs participate in the conversion of human recombinant $\operatorname{PrP}(\mathrm{Sen})$ to $\operatorname{PrP}(\mathrm{Res})$ in vitro. $J$ Mol Biol 332, 47-57.

[117] Macedo B, Cordeiro Y (2017) Unraveling prion protein interactions with aptamers and other PrP-binding nucleic acids. Int J Mol Sci 18, pii: E1023,

[118] Isaacs JD, Jackson GS, Altmann DM (2006) The role of the cellular prion protein in the immune system. Clin Exp Immunol 146, 1-8.

[119] Onodera T, Sakudo A, Tsubone H, Itohara S (2014) Review of studies that have used knockout mice to assess normal function of prion protein under immunological or pathophysiological stress. Microbiol Immunol 58, 361374.

[120] Strittmatter WJ, Weisgraber KH, Huang DY, Dong LM, Salvesen GS, Pericak-Vance M, Schmechel D, Saunders AM, Goldgaber D, Roses AD (1993) Binding of human apolipoprotein $\mathrm{E}$ to synthetic amyloid beta peptide: Isoform-specific effects and implications for late-onset Alzheimer disease. Proc Natl Acad Sci U S A 90, 80988102.

[121] Urrea L, Segura-Feliu M, Masuda-Suzukake M, Hervera A, Pedraz L, Garcia Aznar JM, Vila M, Samitier J, Torrents E, Ferrer I, Gavin R, Hagesawa M, del Rio JA (2017) Involvement of cellular prion protein in alpha-synuclein 
transport in neurons. Mol Neurobiol. doi: 10.1007/s12035017-0451-4.

[122] Beatman EL, Massey A, Shives KD, Burrack KS, Chamanian M, Morrison TE, Beckham JD (2015) Alphasynuclein expression restricts RNA viral infections in the brain. J Virol 90, 2767-2782.

[123] Park SC, Moon JC, Shin SY, Son H, Jung YJ, Kim NH, Kim YM, Jang MK, Lee JR (2016) Functional characterization of alpha-synuclein protein with antimicrobial activity. Biochem Biophys Res Commun 478, 924-928.

[124] Tomlinson JJ, Shutinoski B, Dong L, Meng F, Elleithy D, Lengacher NA, Nguyen AP, Cron GO, Jiang Q, Roberson ED, Nussbaum RL, Majbour NK, El-Agnaf OM, Bennett SA, Lagace DC, Woulfe JM, Sad S, Brown EG, Schlossmacher MG (2017) Holocranohistochemistry enables the visualization of alpha-synuclein expression in the murine olfactory system and discovery of its systemic anti-microbial effects. J Neural Transm 124, 721-738.

[125] De Lorenzi E., Chiari M, Colombo R, Cretich M, Sola L, Vanna R, Gagni P, Bisceglia F, Morasso C, Lin JS, Lee M, McGeer PL, Barron AE (2017) Evidence that the human innate immune peptide LL-37 may be a binding partner of amyloid-beta and inhibitor of fibril assembly. JAlzheimers Dis 59, 1213-1226.
[126] Ueda K, Fukushima H, Masliah E, Xia Y, Iwai A, Yoshimoto M, Otero DA, Kondo J, Ihara Y, Saitoh T (1993) Molecular cloning of cDNA encoding an unrecognized component of amyloid in Alzheimer disease. Proc Natl Acad Sci U S A 90, 11282-11286.

[127] Emamzadeh FN (2016) Alpha-synuclein structure, functions, and interactions. J Res Med Sci 21, 29.

[128] Benestad SL, Austbo L, Tranulis MA, Espenes A, Olsaker I (2012) Healthy goats naturally devoid of prion protein. Vet Res 43, 87.

[129] Richt JA, Kasinathan P, Hamir AN, Castilla J, Sathiyaseelan T, Vargas F, Sathiyaseelan J, Wu H, Matsushita H, Koster J, Kato S, Ishida I, Soto C, Robl JM, Kuroiwa Y (2007) Production of cattle lacking prion protein. Nat Biotechnol 25, 132-138.

[130] Malachin G, Reiten MR, Salvesen O, Aanes H, Kamstra JH, Skovgaard K, Heegaard PMH, Ersdal C, Espenes A, Tranulis MA, Bakkebo MK (2017) Loss of prion protein induces a primed state of type I interferon-responsive genes. PLoS One 12, e0179881. 